\title{
Assessment of Allelopathic Potential of Fennel, Rue and Sage on Weed Species Hoary Cress (Lepidium draba)
}

\author{
Marija RAVLIĆ*, Renata BALIČEVIĆ, Marina NIKOLIĆ, Ankica SARAJLIĆ \\ University ofJosip Juraj Strossmayer in Osijek, Faculty of Agriculture, Department of Plant Protection, Kralja Petra Svačica Id, 31000 Osijek, \\ Croatia;mravlic@pfos.hr(*correspondingauthor);rbalicevic@pfos.hr;nikmarinaa@gmail.com;ankicasarajlic@pfos.hr
}

\begin{abstract}
The current series of experiments was conducted to assess the allelopathic potential of fennel, rue, and sage seed and plant biomass on weed species hoary cress (Lepidium draba). The effect of plants was evaluated through: seed cogermination in Petri dishes, effect of water extracts from fresh and dry plant biomass in two concentrations (50 and $100 \mathrm{~g} \mathrm{l})$ in Petri dishes and pots, and effect of fresh and dry plant residues in rates of 10 and $20 \mathrm{~g} \mathrm{~kg}^{-1}$ of soil. The cogermination of seeds affected germination and seedling length of hoary cress with fennel seeds having the highest inhibitory effect and reducing germination up to $34.9 \%$. The water extracts in Petri dish essay had various effects, however the dry plant biomass in higher concentration reduced germination and seedlings growth for up to $100 \%$. The applications of the extracts from fresh biomass in pots with soil differed from results in Petri dishes. Sage extract in higher concentration inhibited germination for $34.2 \%$, and fennel extract reduced root length for $22.7 \%$. The effect of incorporation of plant residues depended on the plant species and amount of the plant residues and was both stimulatory and inhibitory. The emergence reduction was the highest with incorporation of fresh rue residues.
\end{abstract}

Keywords: allelopathic crops, cogermination, extracts, plant residues, weed control

\section{Introduction}

Weed control with chemical herbicides is certainly an indispensable measure in modern agricultural production, but herbicide application is not possible, desirable, or sufficient in every situation. Excessive use of herbicides leads to various problems, such as weed resistance, herbicide residues, environmental pollution and risk to human health. At the same time, there is an increasing demand for organic products, thus increasing the need to reduce agrochemicals and minimize their negative effect by using a variety of alternative methods such as allelopathy (Singh et al., 2003; Waller, 2004). Allelopathic crops are used in different ways i.e. as surface mulch, incorporated in the soil, as cover crops or as water extracts or pure allelochemicals applied as natural herbicides (Reigosa et al., 2001; Singh et al., 2001). A number of studies reports use of different crops in weed management such as rye, wheat, buckwheat, black mustard and sunflower (Weston, 1996; Soltys et al., 2013), while allelopathic properties of essential oils, extracts and residues of aromatic and medicinal plants are recently being explored (Dhima et al., 2009; De Almeida et al., 2010). Poisonous and medicinal plants from the Mediterranean region represent potential and neglected source of allelochemicals (Aliotta et al., 2008), and among them common rue (Ruta graveolens), sage (Salvia officinalis) and fennel (Foeniculum vulgare) possess certain allelopathic potential on other species (Aliotta et al., 1996; Pirzad et al., 2010; Itani et al., 2013).
Lepidium draba, commonly known as hoary cress, is a perennial herb native to Eastern Europe and Western Asia, and invasive species in North America (Knežević, 2006; Francis and Warwick, 2008). L. draba produces up to 5000 seeds per plant (Hanf, 1970; Knežević, 2006), but also reproduces clonally from intact rhizomes and fragments (Miller $e t$ al., 1994). It is a weed in cereals, row crops, orchards and vineyards, as well as on pastures, along roadsides and on waste areas (Knežević, 2006; Francis and Warwick, 2008).

Therefore, the objective of the study was to evaluate the allelopathic effect of fennel, rue and sage seed and plant biomass on weed species hoary cress through series of experiments in Petri dishes and pots with soil.

\section{Materials and methods}

Collection of plant and seed material and extract preparation

Seeds of fennel, rue and sage used in the experiments were purchased from seed company (Migra d.o.o., Croatia, Sjemenarna d.o.o., B\&H), and weed seeds of hoary cress were collected during 2014 from agricultural fields. Aboveground mass of fennel, rue and sage was harvested in the flowering stage. The proportion of biomass was oven dried at $60^{\circ} \mathrm{C}$ for $48 \mathrm{~h}$, cut into small pieces and ground into fine powder.

Water extracts were prepared according to Norsworthy (2003) from fresh and dry aboveground biomass. One hundred grams of the fresh or dry biomass was mixed with $1000 \mathrm{ml}$ of distilled water and kept for $24 \mathrm{~h}$. The mixtures were filtered through muslin cloth to remove debris and after that through 
filter paper. The obtained extracts were diluted with distilled water to give final concentrations of 5 and 10\% (50 and $100 \mathrm{~g}$ of biomass per litre).

The experiments were conducted twice during 2014, and were laid out as a completely randomized design with four replications.

\section{Petri dish experiments}

The effect of cogermination of aromatic and medicinal crops and weed seeds was investigated according to Đikić (2005) in the first experiment. Each treatment consisted of 30 seeds of aromatic crop and 30 seeds of weed species germinating together in Petri dishes on top of filter paper soaked in distilled water. The control treatment consisted of 30 weed seeds per dish.

In the second experiment the effect of water extracts from fresh and dry biomass in two concentrations on hoary cress was evaluated. Thirty weed seeds were placed in sterilized Petri dishes on top of filter paper. In each Petri dish the equal amount of certain extract was added, while distilled water was used in the control.

\section{Pot experiments}

In the third experiment, the effect of water extracts from fresh biomass of plants in two concentrations was evaluated in pots with soil. In the pots filled with commercial substrate 30 weed seeds were sown and treated in rate of $60 \mathrm{ml}$ of extract per $100 \mathrm{~g}$ of soil. Distilled water was used in the control treatment. Thereafter, all treatments were equally watered.

In the fourth experiment the effect of incorporated fresh and dry residues was determined, according to the modified method of Norsworthy (2003). Fresh or dry plant residues in rates of 10 and $20 \mathrm{~g}$ per $\mathrm{kg}$ of the soil were mixed with commercial substrate. Thirty hoary cress seeds were sown in the pots filled with soil. The control treatment consisted of thirty weed seeds sown in the soil without residues.

\section{Data collection and statistical analysis}

All experiments were kept at $22 \pm 2^{\circ} \mathrm{C}$ temperature and lasted 9 (Petri dish) and 14 days (pot experiment). Germination percentage was calculated using the formula $G(\%)=$ (Germinated seed/Total seed) x 100 in Petri dishes experiments. Emerged seedlings from the pot experiments were counted and percentage of emergence was calculated for each replication using the formula $\mathrm{E}(\%)=($ Emerged seed/Total seed $) \times 100$. The seedlings were uprooted and the length of roots and shoots $(\mathrm{cm})$ and fresh weight $(\mathrm{g})$ were determined.

All collected data was analysed statistically with ANOVA using STATISTICA 7 statistical software (StatSoft, Inc. Tulsa, OK, USA) and differences between treatment means were compared using the LSD-test at probability level of 0.05 .

\section{Results and Discussion}

\section{Seed cogermination}

The cogermination of weed and aromatic and medicinal crop seeds affected germination and seedling length, but had no effect on fresh weight of hoary cress (Table 1.). Germination reduction ranged from 21.2 to $34.9 \%$ and fennel seeds had the highest inhibitory effect. Root length was inhibited significantly only with fennel, and shoot length with rue for $9.3 \%$.
Cogermination of weed and crop seeds can variously affect weed germination and growth and is dependent on both weed and crop species. Seeds of aromatic and medicinal crops from Apiaceae family in other studies showed considerable allelopathic effect. Đikić (2005) found that caraway (Carum carvi), dill (Anethum graveolens) and coriander (Coriandrum sativum) seeds have inhibitory effect on germination of hoary cress up to $65 \%$, and as well as fennel seeds reduce germination of other weed species such as redroot pigweed (Amaranthus retroflexus), smallflower (Galinsoga parviflora) and creeping thistle (Cirsium arvense). The results of the study are also consistent with the results of Ravlić et al. (2013) who demonstrated that coriander and lovage (Levisticum officinale) have negative effect on germination and root length of hoary cress. Plant seeds contain wide range of chemical inhibitors, such as nonprotein amino acids, phenolics (Ketring, 1973; Friedman and Waller, 1983; Rashid et al., 2005) and essential oils (Olle and Bender, 2010) which may negatively affect seed germination. Essential oil components such as thymol, carvon, carvacrol and limonene showed high inhibition against weed seed germination even at low concentrations (Azirak and Karaman, 2008), while trans-anethole, linalool, fenchone, thujone and eugonol exert high to intermediate phytotoxic effect on rigid ryegrass (Lolium rigidum) (Vasilakoglou et al., 2013). Principal constituents of fennel seed volatile oil include anethole and fenchone (Galambosi, 1994) which may have contributed to inhibitory potential of fennel seeds.

\section{Effect of water extracts in Petri dishes}

The extracts prepared from the fresh and dry plant biomass had various effects on germination and growth of hoary cress (Table 2). Germination reduction ranged from 3.5 to $100 \%$, with the extracts from dry biomass in higher concentration showing complete germination inhibition. On average, the fresh biomass extracts reduced germination for up to $17 \%$, while the dry biomass extracts for over $90 \%$. Fennel dry biomass had the highest allelopathic potential.

Both root and shoot length and fresh weight of hoary cress were under positive and negative effect of the extracts applied (Table 2.). Fresh water extracts generally stimulated seedling growth and root length was greater for 4.3 to $56.5 \%$ compared to the control. The exception was fennel extract which reduced root length for 32.9 and $59.1 \%$. Fresh weight was reduced significantly only with higher concentrations of fennel and sage fresh extracts. The extracts from dry biomass reduced seedlings length for over $80 \%$, as well as seedlings fresh weight, especially with the higher concentrations.

Table 1. Effect of cogermination of aromatic and medicinal plants and hoary cress seeds on germination and growth of weed

\begin{tabular}{lcccc}
\hline Treatments & $\begin{array}{c}\text { Germination } \\
(\%)\end{array}$ & $\begin{array}{c}\text { Root length } \\
(\mathrm{cm})\end{array}$ & $\begin{array}{c}\text { Shoot length } \\
(\mathrm{cm})\end{array}$ & $\begin{array}{c}\text { Fresh weight } \\
(\mathrm{g})\end{array}$ \\
\hline Control & $89.3 \mathrm{a}$ & $3.4 \mathrm{a}$ & $2.1 \mathrm{ab}$ & $0.0175 \mathrm{a}$ \\
Fennel & $58.1 \mathrm{c}$ & $2.6 \mathrm{~b}$ & $2.2 \mathrm{a}$ & $0.0176 \mathrm{a}$ \\
Rue & $67.8 \mathrm{bc}$ & $3.1 \mathrm{ab}$ & $1.9 \mathrm{c}$ & $0.0184 \mathrm{a}$ \\
Sage & $70.4 \mathrm{~b}$ & $3.4 \mathrm{a}$ & $2.0 \mathrm{bc}$ & $0.0173 \mathrm{a}$ \\
\hline
\end{tabular}

Means followed by the same letter within the column are not significantly different at $\mathrm{p}<0.05$. 
50

Table 2. Effect of aromatic and medicinal plant water extracts on germination and seedling growth of hoary cress on filter paper in Petri dishes

\begin{tabular}{|c|c|c|c|c|c|}
\hline \multicolumn{2}{|c|}{ Treatments } & $\begin{array}{c}\text { Germination } \\
(\%)\end{array}$ & $\begin{array}{l}\text { Root length } \\
(\mathrm{cm})\end{array}$ & $\begin{array}{l}\text { Shoot length } \\
(\mathrm{cm})\end{array}$ & $\begin{array}{c}\text { Fresh weight } \\
\text { (g) }\end{array}$ \\
\hline \multicolumn{2}{|c|}{ Control } & $86.2 \mathrm{a}$ & $3.2 \mathrm{c}$ & $2.2 \mathrm{bc}$ & $0.0163 \mathrm{~b}$ \\
\hline \multicolumn{6}{|c|}{ Fresh biomass } \\
\hline \multirow[t]{2}{*}{ Fennel } & $50 \mathrm{gl}^{-1}$ & $88.7 \mathrm{a}$ & $2.1 \mathrm{~d}$ & $2.6 \mathrm{a}$ & $0.0175 \mathrm{ab}$ \\
\hline & $100 \mathrm{~g} \mathrm{l}^{-1}$ & $83.2 \mathrm{a}$ & $1.3 \mathrm{e}$ & $2.4 \mathrm{ab}$ & $0.0135 \mathrm{c}$ \\
\hline \multirow[t]{2}{*}{ Rue } & $50 \mathrm{gl}^{-1}$ & $62.4 \mathrm{bc}$ & $5.0 \mathrm{a}$ & $2.7 \mathrm{a}$ & $0.0189 \mathrm{a}$ \\
\hline & $100 \mathrm{~g} \mathrm{l}^{-1}$ & $60.7 c$ & $3.9 \mathrm{~b}$ & $2.3 \mathrm{bc}$ & $0.0161 \mathrm{~b}$ \\
\hline \multirow[t]{2}{*}{ Sage } & $50 \mathrm{gl}^{-1}$ & $66.9 \mathrm{~b}$ & $3.9 \mathrm{~b}$ & $2.3 \mathrm{bc}$ & $0.0157 \mathrm{bc}$ \\
\hline & $100 \mathrm{~g} \mathrm{l}^{-1}$ & $65.9 \mathrm{bc}$ & $3.3 \mathrm{c}$ & $2.1 \mathrm{c}$ & $0.0138 \mathrm{c}$ \\
\hline \multicolumn{6}{|c|}{ Dry biomass } \\
\hline \multirow[t]{2}{*}{ Fennel } & $50 \mathrm{gl}^{-1}$ & $1.8 \mathrm{f}$ & $0.1 \mathrm{~g}$ & $0.1 \mathrm{e}$ & $0.0001 \mathrm{e}$ \\
\hline & $100 \mathrm{~g} \mathrm{l}^{-1}$ & $0.0 \mathrm{f}$ & $0.0 \mathrm{~g}$ & $0.0 \mathrm{e}$ & $0.0000 \mathrm{e}$ \\
\hline \multirow[t]{2}{*}{ Rue } & $50 \mathrm{gl}^{-1}$ & $12.3 \mathrm{e}$ & $0.2 \mathrm{fg}$ & $0.4 \mathrm{~d}$ & $0.0026 \mathrm{~d}$ \\
\hline & $100 \mathrm{~g} \mathrm{l}^{-1}$ & $0.0 \mathrm{f}$ & $0.0 \mathrm{~g}$ & 0.0 e & $0.0000 \mathrm{e}$ \\
\hline \multirow[t]{2}{*}{ Sage } & $50 \mathrm{gl}^{-1}$ & $36.7 \mathrm{~d}$ & $0.3 \mathrm{f}$ & $0.3 \mathrm{de}$ & $0.0021 \mathrm{de}$ \\
\hline & $100 \mathrm{~g} \mathrm{l}^{-1}$ & $0.0 \mathrm{f}$ & $0.0 \mathrm{~g}$ & $0.0 \mathrm{e}$ & $0.0000 \mathrm{e}$ \\
\hline
\end{tabular}

Means followed by the same letter within the column are not significantly different at $\mathrm{p}<0.05$.

Table 3. Effect of water extracts from fresh plant biomass on emergence and growth of hoary cress in soil

\begin{tabular}{|c|c|c|c|c|c|}
\hline \multicolumn{2}{|c|}{ Treatments } & $\begin{array}{c}\text { Emergence } \\
(\%)\end{array}$ & $\begin{array}{l}\text { Root length } \\
(\mathrm{cm})\end{array}$ & $\begin{array}{l}\text { Shoot length } \\
(\mathrm{cm})\end{array}$ & $\begin{array}{c}\text { Fresh weight } \\
\text { (g) }\end{array}$ \\
\hline \multicolumn{2}{|l|}{ Control } & $61.1 \mathrm{bc}$ & $2.8 \mathrm{ab}$ & $3.4 \mathrm{~d}$ & $0.0149 \mathrm{c}$ \\
\hline \multicolumn{6}{|c|}{ Fresh biomass } \\
\hline \multirow[t]{2}{*}{ Fennel } & $50 \mathrm{gl}^{-1}$ & $88.2 \mathrm{a}$ & $2.8 \mathrm{ab}$ & $4.5 \mathrm{a}$ & $0.0217 \mathrm{a}$ \\
\hline & $100 \mathrm{gl}^{-1}$ & $95.6 \mathrm{a}$ & $2.2 \mathrm{c}$ & $4.4 \mathrm{a}$ & $0.0213 \mathrm{a}$ \\
\hline \multirow[t]{2}{*}{ Rue } & $50 \mathrm{gl}^{-1}$ & $54.1 \mathrm{~cd}$ & $2.7 \mathrm{~b}$ & $3.5 \mathrm{~cd}$ & $0.0166 \mathrm{bc}$ \\
\hline & $100 \mathrm{gl}^{-1}$ & $75.5 \mathrm{~b}$ & $2.9 \mathrm{ab}$ & $3.6 \mathrm{~cd}$ & $0.0159 \mathrm{c}$ \\
\hline \multirow[t]{2}{*}{ Sage } & $50 \mathrm{gl}^{-1}$ & $69.7 \mathrm{bc}$ & $3.2 \mathrm{a}$ & $3.8 \mathrm{bc}$ & $0.0181 \mathrm{~b}$ \\
\hline & $100 \mathrm{gl}^{-1}$ & $40.2 \mathrm{~d}$ & $2.9 \mathrm{ab}$ & $3.9 \mathrm{~b}$ & $0.0173 \mathrm{~b}$ \\
\hline
\end{tabular}

Means followed by the same letter within the column are not significantly different at $\mathrm{p}<0.05$.

Extracts from medicinal and aromatic plants show different effects against weeds species. Dhima et al. (2009) reported that extracts from dry plant biomass of fennel, coriander and anise (Pimpinella anisum) show considerable negative effect and suppression of germination, root length and fresh weight of barnyardgrass (Echinochloa crus-galli). Inhibitory potential of sage extract on common purslane (Portulaca oleracea), velvetleat (Abutilon theophrasti), redroot pigweed and wild oat (Avena sterilis) was reported by Pirzad et al. (2010) and Kadioğlu and Yanar (2004). Negative effect of rue was recorded on weed species such as redroot pigweed, common lambsquarter (Chenopodium album), purple nutsedge (Cyperus rotundus), common purslane and flixweed (Descurainia sophia) (Aliotta et al., 2000; Makizadeh et al., 2009). Aliotta et al. (1996) argued that rue infusions and its isolated allelochemicals delayed the onset and decreased the germination and produced damage on the radicals of purslane seedlings. Medicinal plants may contain various bioactive compounds, and volatile terpenes and essential oils can be applied as weed growth regulators (Arminante et al., 2006). Sage oil principal components include 1,8-cineole, $\alpha$ thujone and $\beta$-pinene (Mirjalili et al., 2006). Furanocoumarins 5methoxypsoralen (5-MOP), 8-methoxypsoralen (8-MOP), and the quinolone alkaloid graveoline isolated from rue extracts cause growth reduction through cell leakage and inhibition of cell division (Hale et al., 2004). Ethanolic and aqueous extracts of fennel seed contain a high phenolic content (Oktay et al., 2003), while major phenolic compounds of methanolic extract of fennel plant material include caffeoylquinic, chlorogenic, dicaffeoylquinic, and rosmarinic acids (Križman et al., 2007).

Generally, the extracts from the fresh plant biomass showed lower inhibitory effect than extracts from the dry plant biomass, and even promoted root and shoot length. The differences among extracts prepared from fresh or dry biomass may be due to the different concentration of active substances extracted from the fresh and dry plant tissues (Marinov-Serafimov, 2010). Lower concentrations of allelochemicals generally have lesser or stimulatory effect on the plant growth, while negative effect increases with the increase in concentration (Dhima et al., 2009; Konstantinović et al., 2014). However, Qasem (1995) indicates that even dry biomass may exhibit lower inhibitory potential than fresh since harmful effect could be greatly reduced during drying process. Greater reduction in germination and growth of hoary cress seedlings were observed by Baličević et al. (2014) and Ravlić et al. (2014) when extracts from dry biomass of marigold (Calendula officinalis L.) and parsley (Petroselinum crispum) were used compared to extracts from fresh biomass. The $\mathrm{pH}$ and osmotic potential of the extracts as well as higher concentration of mineral nutrients and other organic compounds may result in reduced water uptake and exert greater negative effect on seed germination and seedlings development (Qasem, 2010).

\section{Effect of water extracts in pots with soil}

The application of extracts from the fresh biomass caused reduction in weed seedlings emergence only in the treatment with sage extract in higher concentration and amounted up to $34.2 \%$ compared to the control (Table 3 ). On the other hand, fennel extract in both concentrations greatly stimulated germination for 44.3 and $56.4 \%$. Significant reduction of root length was recorded only in the treatment with $10 \%$ fennel extract for $22.7 \%$. Shoot length and fresh weight of hoary cress seedlings were stimulated with all extracts applied and fennel extracts promoted shoot length and fresh weight up to 33.7 and $46.3 \%$, respectively.

Results obtained from the experiments with extracts from the fresh plant biomass somewhat differed considering whether Petri dishes or pots with soil were used. For example, seedling emergence in the treatments with fennel was highly promoted in the soil, while in Petri dish assay germination was not affected. On the other hand, sage extract in lower concentration promoted seedling emergence oppose to the germination inhibition in Petri dishes. Likewise, stimulatory effect was sometimes more pronounced on the filter paper than in the soil and conversely.

The differences between results could be due to higher amount of extract applied to the soil which enhanced positive or negative effect (Ravlić et al., 2014), or because allelochemicals diffused and degraded in the soil (Vidal et al., 1998) while seeds on filter paper had direct contact with the extracts. 
Table 4. Effect of aromatic and medicinal plant residues on germination and seedling length of hoary cress

\begin{tabular}{|c|c|c|c|c|c|}
\hline \multicolumn{2}{|c|}{ Treatments } & $\begin{array}{c}\text { Emergence } \\
(\%)\end{array}$ & $\begin{array}{l}\text { Root length } \\
(\mathrm{cm})\end{array}$ & $\begin{array}{l}\text { Shoot length } \\
\quad(\mathrm{cm})\end{array}$ & $\begin{array}{c}\text { Fresh weight } \\
\text { (g) }\end{array}$ \\
\hline \multicolumn{2}{|l|}{ Control } & $63.3 \mathrm{bc}$ & $2.9 \mathrm{a}$ & $4.2 \mathrm{abc}$ & $0.0221 \mathrm{~cd}$ \\
\hline \multicolumn{6}{|c|}{ Fresh residues } \\
\hline \multirow[t]{2}{*}{ Fennel } & $10 \mathrm{~g} \mathrm{~kg}^{-1}$ & $47.9 \mathrm{~cd}$ & $1.9 \mathrm{dc}$ & $3.5 \mathrm{~d}$ & 0.0177 ef \\
\hline & $20 \mathrm{~g} \mathrm{~kg}^{-1}$ & $73.7 \mathrm{~b}$ & $1.5 \mathrm{~d}$ & $3.8 \mathrm{~cd}$ & $0.0182 \mathrm{def}$ \\
\hline \multirow[t]{2}{*}{ Rue } & $10 \mathrm{~g} \mathrm{~kg}^{-1}$ & $46.9 \mathrm{~cd}$ & $3.0 \mathrm{a}$ & $3.8 \mathrm{~cd}$ & $0.0163 \mathrm{f}$ \\
\hline & $20 \mathrm{~g} \mathrm{~kg}^{-1}$ & $40.6 \mathrm{~d}$ & $3.0 \mathrm{a}$ & $3.9 \mathrm{bcd}$ & $0.0189 \mathrm{def}$ \\
\hline \multirow[t]{2}{*}{ Sage } & $10 \mathrm{~g} \mathrm{~kg}^{-1}$ & $51.2 \mathrm{~cd}$ & $2.9 \mathrm{a}$ & $4.1 \mathrm{abc}$ & $0.0215 \mathrm{cde}$ \\
\hline & $20 \mathrm{~g} \mathrm{~kg}^{-1}$ & $77.5 \mathrm{~b}$ & $3.0 \mathrm{a}$ & $4.5 \mathrm{a}$ & $0.0249 \mathrm{bc}$ \\
\hline \multicolumn{6}{|l|}{ Dry res } \\
\hline \multirow[t]{2}{*}{ Fennel } & $10 \mathrm{~g} \mathrm{~kg}^{-1}$ & $75.6 \mathrm{~b}$ & $1.7 \mathrm{~d}$ & $4.1 \mathrm{abc}$ & $0.0217 \mathrm{cde}$ \\
\hline & $20 \mathrm{~g} \mathrm{~kg}^{-1}$ & $93.2 \mathrm{a}$ & $2.0 \mathrm{dc}$ & $4.2 \mathrm{abc}$ & $0.0266 \mathrm{~b}$ \\
\hline \multirow[t]{2}{*}{ Rue } & $10 \mathrm{~g} \mathrm{~kg}^{-1}$ & $58.4 \mathrm{bcd}$ & $2.3 \mathrm{bc}$ & $4.5 \mathrm{a}$ & $0.0268 \mathrm{~b}$ \\
\hline & $20 \mathrm{~g} \mathrm{~kg}^{-1}$ & $61.8 \mathrm{bcd}$ & $1.7 \mathrm{~d}$ & $4.2 \mathrm{abc}$ & $0.0322 \mathrm{a}$ \\
\hline \multirow[t]{2}{*}{ Sage } & $10 \mathrm{~g} \mathrm{~kg}^{-1}$ & $62.2 \mathrm{bcd}$ & $2.9 \mathrm{a}$ & $4.4 \mathrm{ab}$ & $0.0279 \mathrm{ab}$ \\
\hline & $20 \mathrm{~g} \mathrm{~kg}^{-1}$ & $69.3 \mathrm{bc}$ & $2.7 \mathrm{ab}$ & $4.2 \mathrm{abc}$ & $0.0280 \mathrm{ab}$ \\
\hline
\end{tabular}

Means followed by the same letter within the column are not significantly different at $\mathrm{p}<0.05$.

\section{Effect of plant residues in pots with soil}

The emergence of weed seedlings was not significantly affected when plant residues were incorporated, except in the treatments with fresh rue residues in $20 \mathrm{~g} \mathrm{~kg}^{-1}$ which had inhibitory and dry fennel residues in $20 \mathrm{~g} \mathrm{~kg}^{-1}$ which had stimulatory effect (Table 4). However, higher residue rates had higher effect. Reduction of root length ranged from 8.2 to $46.6 \%$ with fresh and dry fennel residues and dry rue residues showing the highest negative potential. Shoot length on the other hand was significantly reduced only with fennel fresh residues in lower rate. Fresh weight of seedlings was inhibited with lower rates of fresh fennel and rue residues for 20.1 and 26.4\%, respectively. All dry residues, except for fennel in $20 \mathrm{~g} \mathrm{~kg}^{-1}$ rate, had significant stimulatory effect on weed fresh weight, up to $45.9 \%$. On average, fresh plant residues had higher inhibitory effect on emergence percent, shoot length and fresh weight of hoary cress.

Incorporation of plant residues in soil can be both stimulatory and inhibitory and the results clearly indicate that differences in the allelopathic potential depended on the plant species, amount and condition of residues. Oliva $e t$ al. (2002) reported severe reduction in emergence of crops when rue leaves were incorporated or used as mulch. Results indicated that soil with rue leaves had higher values of watersoluble phenolics, electrical conductivity and nitrate, and lower $\mathrm{pH}$ values compared to the untreated soil. Similarly, plants of fennel, parsley, and dill according to Dhima et al. (2009) incorporated as green manure reduced plant number of barnyardgrass, common purslane and common lambsquarters. On the other hand, Baličević et al. (2014) stated that marigold fresh and dry residues promoted emergence and growth of hoary cress. Aromatic plants with the capacity to produce phytotoxic essential oils could play an important role for weed suppression in sustainable agriculture systems (Dhima et al., 2009).

\section{Conclusions}

The fennel, the rue and the sage seed and the plant biomass have both positive and negative allelopathic effect on weed species hoary cress. Negative allelopathic effect depended on the aromatic and medicinal plant species, concentration or whether the fresh or dry biomass was used. Certain extracts from the fresh biomass showed weed inhibition both in Petri dish and pots assays. The results also indicate that the fresh residues of plants and their incorporation could be used to suppress weed germination and fresh weight. Allelopathic effect was different depending on the media used which shows the need for conducting experiments both on the filter paper and in the soil.

\section{References}

Aliotta G, Cafiero G, De Feo V, Di Blasio B, lacovino R, Oliva A (2000). Allelochemicals from rue (Ruta graveolens $\mathrm{L}$.) and olive (Olea europaea $\mathrm{L}$.) oil mill waste waters as potential natural pesticides. Current Topics in Phytochemistry3:167-177.

Aliotta G, Cafiero G, De Feo V, Palumbo AD, Strumia S (1996). Infusion of rue for control of purslane weed: Biological and chemical aspects. AllelopathyJournal3(2):207-216.

Aliotta G, Mallik AU, Pollio A (2008). Historical examples of allelopathy and ethnobotany from the Mediterranean region. In: Zeng RS, Mallik AU, LuoSM(Eds). Allelopathy in sustainable agriculture and forestry. Springer Science and Business MediaNew York.

Arminante F, De Falco E, De Feo V, De Martino L, Mancini E, Quaranta F (2006). Allelopathic activity of essential oils from Mediterranean Labiate. ActaHorticulturae 723:347-356.

Azirak S, Karaman S (2008). Allelopathic effect of some essential oils and components on germination of weed species. Acta Agriculturae Scandinavica, Section B-Soil and Plant Science 58(1):88-92.

Baličević R, RavlićM, KneževićM, MarićK, MikićI (2014). Effect of marigold (Calendula officinalis L.) cogermination, extracts and residues on weed species hoary cress (Cardaria draba(L.)Desv.).Herbologia 14(1):23-32.

De Almeida LFR, Frei F, Mancini E, De Martino L, De Feo V. (2010). Phytotoxic activities of Mediterranean essential oils. Molecules 15:43094323.

Dhima KV, Vasilakoglou IB, Gatsis ThD, Panou-Pholotheou E, Eleftherohorinos IG (2009). Effects of aromatic plants incorporated as green manure on weed and maize development. Field Crops Research 110:235-241.

Đikić M (2005). Allelopathic effect of cogermination of aromatic and medicinal plants and weed seeds. Herbologia 6(1):15-24.

Francis A, Warwick SI (2008). The biology of Canadian weeds. 3. Lepidium draba L, L. chalepense L, L. appelianum Al-Shehbaz (updated). Canadian Journal of PlantScience 88(2):379-401.

Friedman J, Waller GR (1983). Seeds as allelopathic agents. Journal of ChemicalEcology 9(8):1107-1117.

GalambosiB(1994). ØkologiskUrtedykingiNorden.NLH-Fagtjenesten. 
52

Hale AL, Meepagala KM, Oliva A, Aliotta G, DukeSO (2004). Phytotoxins from the leaves of Ruta graveolens. Journal of Agricultural and Food Chemistry 52(11):3345-3349.

Hanf M (1970). Weeds and their seedlings. BASF United Kingdom Ltd, Ipswich, UK.

Itani T, Nakahata Y, Kato-Naguchi H (2013). Allelopathic activity of some herb plant species. International Journal of Agriculture and Biology 15:1359-1362.

Kadioğlu I, Yanar Y (2004). Allelopathic effects of plant extracts against seed germination of some weeds. Asian Journal of Plant Sciences 3(4):472475.

Ketring DL (1973). Germination inhibitors. Seed Science Technology 1:305-224.

Knežević M (2006). Atlas korovne, ruderalne i travnjačke flore. Sveučilište u Osijeku Poljoprivredni fakultet, Osijek.

Konstantinović B, Blagojević M, Konstantinović B, Samardžić N (2014). Allelopathic effect of weed species Amaranthus retroflexus $\mathrm{L}$. on maize seed germination. Romanian Agricultural Research 31:315-321.

Križman M, Baričevič D, Prošek M (2007). Determination of phenolic compounds in fennel by HPLC and HPLC-MS using monolithic reverse-phase column. Journal of Pharmaceutical and Biomedical Analysis 43(2):481-485.

Makizadeh MT, Salimi M, Farhoudi R (2009). Allelopathic effect of rue (Ruta graveolens L.) on seed germination of three weeds. Iranian Journal of Medicinal and Aromatic Plants 24(4):463-471.

Marinov-Serafimov P (2010). Determination of allelopathic effect of some invasive weed species on germination and initial development of grain legume crops. Pesticides and Phytomedicine 25(3):251-259.

Miller RF, Svejcar TJ, Rose JA, McInnis ML (1994). Plant development, water relations, and carbon allocation of heart-podded hoary cress. Agronomy Journal 86:487-491.

Mirjalili MH, Salehi P, Sonboli A, Mohammadi V (2006). Essential oil variation of Salvia officinalis aerial parts during its phenological cycle. Chemistry of Natural Compounds 42:19-23.

Norsworthy JK (2003). Allelopathic potential of wild radish (Raphanus raphanistrum). Weed Technology 17:307-313.

Oktay M, Gülçin İ, Küfrevioğlu Öİ (2003). Determination of in vitro antioxidant activity of fennel (Foeniculum vulgare) seed extracts. Lebensmittel-Wissenschaft und-Technologie 36:263-271.

Oliva A, Lahoz E, Contillo R, Aliotta G (2002). Effects of Ruta graveolens leaves on soil characteristics and early seedling growth of four crop species. Annals of Applied Biology 141:87-91.

Olle M, Bender I (2010). The content of oils in umbelliferous crops and its formation. Agronomy Research 8:687-696.

Pirzad A, Ghasemian V, Darvishzahed R, Sedghi M, Hassani A, Onofri A (2010). Allelopathy of sage and white wormwood on purslane germination and seedling growth. Notulae Scientia Biologicae 2(3):91-95.
Qasem JR (2010). Differences in the allelopathy results from field observations to laboratory and glasshouse experiments. Allelopathy Journal 26(1):45-58.

Qasem JR (1995). Allelopathic effects of Amaranthus retroflexus and Chenopodium murale on vegetable crops. Allelopathy Journal 2(1):49-66.

Rashid A, Furness NH, Ellis BE, Upadhyaya MK (2005). Inhibition of seed germination and seedling growth by hound's tongue (Cynoglossum officinale L.) seed leachate. Weed Biology and Management 5:143-149.

Ravlić M, Baličević R, Lucić I (2014). Allelopathic effect of parsley (Petroselinum crispum Mill.) cogermination, water extracts and residues on hoary cress (Lepidium draba (L.) Desv.). Poljoprivreda 20(1):22-26.

Ravlić M, Baličević R, Pejić T, Pećar N (2013). Allelopathic effect of cogermination of some aromatic plants and weed seeds. Proceedings and abstracts of the $6^{\text {th }}$ International Scientific/Professional Conference Agriculture in Nature and Environment Protection. Glas Slavonije, Osijek, pp 104-108.

Reigosa MJ, Gonzáles L, Sánchez-Moeriras A, Durán B, Puime D, Fernández D, Bolano JC (2001). Comparison of physiological effects of allelochemicals and commercial herbicides. Allelopathy Journal 8:211-220.

Singh P, Batish DR, Kohli RK (2001). Allelopathy in agroecosystems. An overview. Journal of Crop Production 4(2):1-41.

Singh HP, Batish DR, Kohli RK (2003). Allelopathic interactions and allelochemicals: New possibilities for sustainable weed management. Critical Review in Plant Sciences 22:239-311.

Soltys D, Krasuska U, Bogatek R, Gniazdowska A (2013). Allelochemicals as Bioherbicides-Present and Perspectives. In: Price AJ, Kelton JA (Eds). Herbicides- Current Research and Case Studies in Use. CC BY,pp 517-542.

Vasilakoglou I, Dhima K, Paschalidis K, Ritzoulis C (2013). Herbicidal potential on Lolium rigidum of nineteen major essential oil components and their synergy. Journal of Essential Oil Research 25(1):1-10.

Vidal RA, Hickman MV, Bauman TT (1998). Phenolics adsorption to soil reduces their allelochemical activity. Pesquisa Agropecuaria Gaúcha 4(2):125-129.

Waller GR (2004). Introduction-reality and future of allelopathy. In: Macias FA, Galindo JCG, Molinilla HMG, Cutler HG (Eds). Allelopathy: chemistry and mode of action of allelochemicals, CRC Press Boca Raton Florida USA pp 1-12.

Weston LA (1996). Utilization of allelopathy for weed management in agroecosystems. Agronomy Journal 88:860-866. 